\title{
Evaluation of thermal stress indexes for dairy cows in tropical regions
}

\section{Roberto Gomes da Silva ${ }^{1}$, Débora Andréa Evangelista Façanha Morais ${ }^{2}$, Magda Maria Guilhermino ${ }^{3}$}

\footnotetext{
${ }^{1}$ Departamento de Zootecnia, Faculdade de Ciências Agrárias e Veterinárias, Universidade Estadual Paulista, Jaboticabal, SP

2 Departamento de Ciência Animal, Universidade Federal Rural do Semi-Árido, Mossoró, RN.

${ }^{3}$ Departamento de Agropecuária, Centro de Tecnologia, Universidade Federal do Rio Grande do Norte, Natal, RN.
}

\begin{abstract}
Data from 359 Holstein and 54 Jersey cows (total of 1359 observations) collected in commercial herds in the northeast of Brazil were used to evaluate six environmental stress indexes. The selection criterion was the correlation between the index value with the rectal temperature (RT) and the respiratory rate (RR) of cows. Both Temperature-Humidity Index (THI) and Black Globe-Humidity Index (BGHI) had the lowest correlations with animal RT and RR. The selected indexes were the Equivalent Temperature Index $(r=0.293$ and 0.520 with RT and RR, respectively) and the Heat Load Index $(0.286$ and 0.542 , respectively).
\end{abstract}

Key Words: dairy cattle, thermal comfort index, tropical environment

\section{Escolha de índices de estresse térmico para vacas leiteiras em ambiente tropical}

RESUMO - Seis índices de estresse ambiental foram aplicados a 1.359 dados de 359 vacas Holandesas e 54 vacas Jersey em rebanhos comerciais do Ceará e Rio Grande do Norte. O critério de seleção aplicado aos índices foi sua correlação com a temperatura retal e a freqüência respiratória dos animais. O Índice de Temperatura e Umidade (THI) e o Índice de Globo e Umidade (BGHI) apresentaram os piores resultados, com correlações muito baixas com as respostas dos animais. Os índices escolhidos foram o Índice de Temperatura Equivalente (ESI), correlacionado significativamente com a temperatura retal $(\mathrm{r}=0,293)$ e a freqüência respiratória $(\mathrm{r}=0,520)$, e o Índice de Carga Térmica (HLI), com correlações $\mathrm{r}=0,286$ e $\mathrm{r}=0,542$ respectivamente.

Palavras-chave: ambiente tropical, gado leiteiro, índices de conforto térmico

\section{Introduction}

The animal's environment is very complex. Nevertheless, scientists attempt to define and measure it in terms of a single parameter or a small group of parameters considered of primary importance. Of various measures of the thermal environment, dry-bulb temperature is generally considered to be the principal thermal measure. However, high humidity or solar radiation worsens the effect of high temperature. High humidity reduces the potential for skin and respiratory evaporation by the animal, while solar radiation adds to the heat from metabolic processes which must be dissipated to maintain body temperature. Wind reduces adverse effects of high temperatures, while thermal radiation from warmer surroundings amplifies them, especially in tropical regions.

Integrative measures have been developed to evaluate microclimates of animals in hot weather, e.g. the black globe thermometer, which combines the influence of air temperature, air movement and radiation (Vernon, 1932; Bedford \& Warner 1934; Bond \& Kelly, 1955; Silva 2002). However, the globe temperature is a consequence of the specific thermal behaviour of a globe with given dimensions, made of a given material and exposed to circumstantial conditions in a given space point, while animal bodies are of very different and variable size, shape and structure. Thus, the black globe should not be taken as a general model for animals, as for the exchange of thermal energy with environment. An adequate integrative measure of the thermal environment, either in hot and in cold weather, must be based on the knowledge of the thermal exchange mechanisms of a given animal type. Electrical animal analogues have been suggested with this purpose (McArthur, 1987; Silva, 2000b; McGovern \& Bruce, 2000; Turnpenny, $2000 \mathrm{a}, \mathrm{b})$. 
Indices derived from primary meteorological measures have been developed by Thom (1959), Buffington et al. (1981), Yamamoto (1983), Baeta et al. (1987), Silva \& Barbosa (1993), Moran et al. (2001), Gaughan et al. (2002) and Eigenberg et al. (2002, 2003); a comprehensive review on the assessment of thermal indices for livestock was presented by Hahn et al. (2003). Indices as those previously mentioned are useful devices to evaluate the general climate of an area; they involve local meteorological measures of the air temperature and humidity, wind speed, mean radiant temperature and solar radiation, but the variables and their coefficients in a given index must be consistent with the physiological mechanisms of heat exchange of the animals under consideration.

Animals function most efficiently within their thermoneutral zone, while above the upper and the lower critical temperatures animals are stressed and the environment constrains the production process. However, those critical temperatures are not fixed characteristics for any species or animal type and they may change with age and physiological conditions. Natural and artificial selection in extreme environments can improve adaptation for those conditions, by changing $\%$ sometimes in few generations \% the adaptive morphological and physiological traits of livestock. For example, Holstein cows bred in tropical and subtropical zones have differences in their hair coat characteristics relative to the cows bred in temperate regions (Udo, 1978; Pinheiro \& Silva (1998). Thus, one must be careful as for the choice of a thermal comfort index to be used in a tropical environment; for in this ambient the heat exchange mechanisms have relative importance different from that they show in temperate regions.

The purpose of the present paper is to compare some published thermal comfort indices, testing them on dairy cows adapted to and bred under the conditions of a tropical environment with high levels of solar radiation, with the aim of to point an index among them adequate to help breeders to choice management procedures.

\section{Materials and Methods}

There were used 359 Holstein cows in four herds, three of them (200 cows) located in Quixeramobim, Ceará (5011'57" South latitude, $39^{\circ} 17^{\prime} 34^{\prime \prime}$ West longitude, 212 m altitude) and one (159 cows) in Macaiba, Rio Grande do Norte (5'51'30" South, 35021'14"West, 10 m altitude); there were measured also 54 Jersey cows of a herd in Monte Alegre, Rio Grande do Norte (6 $6^{\circ} 04^{\prime} 04^{\prime \prime}$ South, 35¹9'56" West, 30 m altitude). These locations are representative of the two main environments of the northeast region, the semi-arid zone (interior of the States of Ceará and Rio Grande do Norte) and the relatively humid eastern coast of Rio Grande do Norte, respectively. The former zone present high temperatures along the year $\left(25\right.$ to $\left.35^{\circ} \mathrm{C}\right)$, low air humidity, average wind speed of $9.6 \mathrm{~m} . \mathrm{s}^{-1}$ and high levels of solar radiation. In the eastern coastal region of Rio Grande do Norte the relative humidity is about $65 \%$ the year around and is well provided of water and pasture. It is showed in Figure 1 that solar radiation is always high in these regions, with peaks in the vernal and autumnal equinoxes; air temperatures were about $30^{\circ} \mathrm{C}$ during the year, but rarely reach above $35^{\circ} \mathrm{C}$, especially in the east coast of Rio Grande do Norte.

The animals were subjected to similar management practices in all locations. In the dry season they were maintained in pens provided with shelters and feeders, receiving concentrate, hay and chopped forage. In the rainy season the cows remained during the day in the pasture between the milkings, which was mechanically performed in a parlour twice a day.

The animals were taken at random from the respective herds and observed in all year seasons, most of them more than once. Milking cows only were considered, with an average production of $15 \mathrm{~kg} / \mathrm{cow} / \mathrm{day}$. On each day of observation, a group of 30 to 40 cows were driven at 09:00h to a corral, where they remained exposed to sun until the solar noon $(11: 20 \mathrm{~h})$; at this time they were measured for the rectal temperature $\left(T_{r}\right)$ and respiratory rate $\left(F_{r}\right)$. These two measurements were taken as estimates of the animals' reaction to the thermal stress.

$T_{r}$ and $F_{r}$ measurements were done together with determinations of environmental data: dry bulb temperature $\left(T_{a}\right)$, wet bulb temperature $\left(T_{w}\right)$, black globe temperature $\left(T_{g}\right)$ and wind speed $(V)$. Measurements of $T_{a}$ and $T_{w}$ were performed by means of a ventilated psychrometer and used to estimate air temperature $\left(T_{a}\right)$, relative humidity $\left(U_{r}\right)$, and partial air vapour pressure $\left(P_{v}\right)$; wind speed was measured with a digital anemometer (Sper Scientific). $T_{g}$ was measured with a $15 \mathrm{~cm}$ diameter black globe and used to estimate the mean radiant temperature $\left(T_{r m}\right)$ by using the formulae presented by Silva (2000a, 2002). All these temperatures were taken in Celsius degrees.

In addition, estimates of the solar radiation were obtained for each location, by using the following formulae:

(1) Zenith angle of sun:

$\cos \theta=\left(\cos L_{\mathrm{t}}\right)(\cos \delta)(\cos \eta)+\left(\operatorname{sen} L_{\mathrm{t}}\right)(\operatorname{sen} \delta)$ 


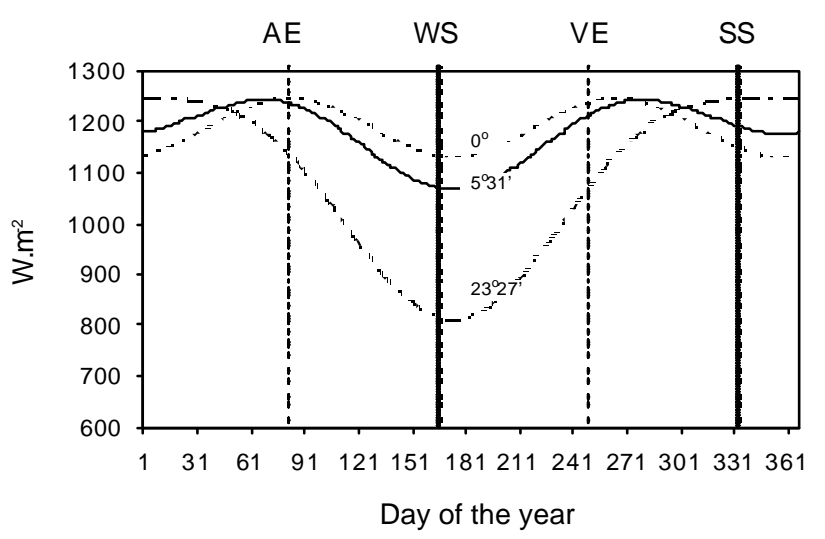

Figure 1 - Annual variation of the solar irradiance at sea level at noon in the following latitudes: $0^{\circ}$ (equator), $5^{\circ} 31$ south and $23^{\circ} 27^{\prime}$ south (tropic of Capricorn). AE is the autumnal equinox, WS is winter solstice, VE is vernal equinox and $S S$ is the summer solstice.

where $L_{\mathrm{t}}$ is the latitude (in decimal degrees), $\delta$ is the declination of sun:

$\boldsymbol{\delta}=23.45 \operatorname{sen}\left[\frac{360}{365.242}(284+d]\right.$

where $d$ is the day of the year ( $d=1$ for January $1^{\text {st }}$ ) andh is the hour angle of sun,

$\eta=15\left(h-12-\frac{45-L_{\mathrm{g}}}{15}\right)$

where $h$ is the hour (legal time) and $L_{\mathrm{g}}$ is the longitude (decimal degrees).

(2) Solar irradiance:

$$
S=1372,9 \cos \Theta e^{-t m}[1-n(1-c)], \mathrm{W} \cdot \mathrm{m}^{-2}
$$

where $t$ is the atmospheric turbidity coefficient (Monteith \& Unsworth, 1990), $m$ is air mass, $n$ is the proportion of sky covered by clouds and $c$ is a coefficient based on the type of clouds. For an exceptionally clean atmosphere a value $t=0.1$ can be of choice, but it can be normally $t=0.25$; as the altitudes of the considered locations were low, air mass was given as $m=1 / \cos \theta$. The value of $n$ can be given by visual inspection of the sky, while that of $c$ was taken from the table of List (1971). This table shows a value $c=1$ for a clean sky, $c=0.85$ for cirrus-stratus clouds, $c=0.35$ for stratus-cumulus, $c=0.25$ for stratus and so on; it must be considered as the predominant type of cloud. As for the region considered in the present study, cirrus-stratus is generally the predominant cloud type.

Six indices were considered: (a) Temperature-Humidity Index (Thom, 1959):

$\mathrm{THI}=T_{a}+0.36 T_{p o}+41.5$

where $T_{p o}$ is the dew-point temperature $\left({ }^{\circ} \mathrm{C}\right)$;

(b) Black Globe-Humidity Index (Buffington et al., 1981):

$\mathrm{BGHI}=T_{g}+0.36 T_{p o}+41.5$

(c) Equivalent Temperature Index (Baeta et al., 1987):

$$
\begin{aligned}
\mathrm{ETI}= & 27.88-0.456 T_{a}+0.010754 T_{a}^{2}-0.4905 U_{r}+0.00088 U_{r}^{2}+1.1507 V- \\
& -0.126447 V^{2}+0.019876 T_{a} U_{r}-0.046313 T_{a} V
\end{aligned}
$$

(d) Environmental Stress Index (Moran et al., 2001):

$$
\mathrm{ESI}=0.63 T_{a}-0.03 U_{r}+0.002 S+0.0054 T_{a} U_{r}-0.073(0.1+S)^{-1}
$$

(e) Heat Load Index (Gaughan et al., 2002):

$\mathrm{HLI}=33.2+0.2 U_{r}+1.2 T_{g}^{*}-(0.82 V)^{0.1}-\log \left(0.4 V^{2}+0.0001\right)[9]$ where $T_{g}^{*}=1.33 T_{a}-2.65 T_{a}^{1 / 2}+3.21 \log (S+1)+3.5$ is the predicted globe temperature $\left({ }^{\circ} \mathrm{C}\right)$.

(f) Respiratory Rate Predictor (Eigenberg et al., 2002, 2003):

$\mathrm{PRR}=5.4 T_{a}+0.58 U_{r}-0.63 V+0.024 S-110.9$

This last formula is for animals exposed to sun with no shade. Eigenberg et al. (2002) give a different index for shaded animals.

The above indexes were calculated for each combination of environmental variables corresponding to the measurements made in the animals, in order to assure that each animal response was associated to a given environmental condition.

\section{Results and Discussion}

Table 1 shows the average values of the environmental variables and animal traits measured in the two locations. Although it is generally believed that the semi-arid region (here represented by Quixeramobim) has a more stressful environment than that of the east coast of Rio Grande do Norte, the animals observed in Quixeramobim presented $T_{r}$ and $F_{r}$ averages lower than those in Macaíba and Monte Alegre, where the mean radiant temperatures were significantly lower compared to those in Quixeramobim. Such differences in animals' response were due probably to the higher air humidity in Macaiba and Monte Alegre, 
Table 1 - Average values of environmental and animal measurements collected in three locations

\begin{tabular}{lccc}
\hline Measurement & Quixeramobim - CE & Macaíba - RN & Monte Alegre - RN \\
\hline Number of observations & 1146 & 159 & 54 \\
Rectal temperature $\left({ }^{\circ} \mathrm{C}\right)$ & $39.22 \pm 0.01$ & $39.89 \pm 0.03$ & $39.53 \pm 0.08$ \\
Respiratory rate $\left(\mathrm{min}^{-1}\right)$ & $43.5 \pm 0.2$ & $75.9 \pm 1.0$ & $79.6 \pm 2.3$ \\
Air temperature $\left({ }^{\circ} \mathrm{C}\right)$ & $29.44 \pm 0.08$ & $31.04 \pm 0.15$ & $29.73 \pm 0.22$ \\
Wind speed $\left(\mathrm{m} . \mathrm{s}^{-1}\right)$ & $3.03 \pm 0.04$ & $2.21 \pm 0.03$ & $1.66 \pm 0.10$ \\
Partial vapour pressure $(\mathrm{k} . P a)$ & $2.62 \pm 0.01$ & $3.03 \pm 0.01$ & $3.32 \pm 0.02$ \\
Mean radiant temperature $\left({ }^{\circ} \mathrm{C}\right)$ & $77.45 \pm 0.31$ & $69.22 \pm 0.83$ & $59.46 \pm 1.79$ \\
\hline
\end{tabular}

which lead to a reduced latent heat transfer by respiratory and cutaneous evaporation. Besides, in this last region the average wind speed was lower during the observation period, thus contributing to reduce heat losses by sweating and convection. It must be noticed that the observations in Quixeramobim were done the year along, while in Monte Alegre and Macaiba the animals were measured in the late February and early March respectively, when solar radiation reaches its maximum in these locations.

It must be noted that all the locations studied presented high values of the mean radiant temperature, whichaveraged from $59.46 \pm 1.79^{\circ} \mathrm{C}$ in Monte Alegre to $77.45 \pm 0.31^{\circ} \mathrm{C}$ in the semi-arid area of Quixeramobim while the respective averages of air temperature were $29.73 \pm 0.22^{\circ} \mathrm{C}$ and $29.44 \pm$ $0.08^{\circ} \mathrm{C}$. The $T_{\mathrm{rm}}$ values are much higher than those observed in temperate zones, which remain generally near that of the air temperature. Thus, thermal radiation is an environmental factor of prime importance in tropical regions.

The six indexes were applied to the cows' data and the correlations with animals' response $\left(T_{r}\right.$ and $\left.F_{r}\right)$ calculated. The values of these correlations were assumed as indications of the efficiency of each index as indicators of the animals' response to the environment. Table 2 shows these results. In addition, the respective regression curves were calculated and presented in Figures 2 to 7.

The THI index has been widely used to evaluate environments for livestock breeding even in tropical regions, despite its obvious limitations, under the argument that it is correlated with animal production performance. Of course, this argument could be valid for temperate zones (where the index was developed), but this index presented the worst results in the present evaluation, as it can be observed in Table 2. The BGHI index $\%$ a modification of THI \% showed also very low correlations with animals' responses to thermal environment under the conditions of a equatorial region.

The indexes with the highest rank for the tropical conditions were ETI and HLI, which presented similar significant correlations with $T_{r}$ and $F_{r}$. Figures 4 and 6
Table 2 - Correlation coefficients of six indexes calculated for Holstein and Jersey cows with animals' response to a tropical environment

\begin{tabular}{lcc}
\hline Index & Rectal temperature & Respiratory rate \\
\hline $\begin{array}{l}\text { THI } \\
\text { Thom (1959) }\end{array}$ & $-0.053 \mathrm{~ns}$ & $0.099^{* *}$ \\
$\begin{array}{l}\text { BGHI } \\
\text { Buffington et al. (1981) }\end{array}$ & $0.054 \mathrm{~ns}$ & $0.155^{* *}$ \\
$\begin{array}{l}\text { E T I } \\
\text { Baeta et al. (1987) }\end{array}$ & $0.293^{* *}$ & $0.520^{* *}$ \\
$\begin{array}{l}\text { ESI } \\
\text { Moran et al. (2001) }\end{array}$ & $0.209 * *$ & $0.464 * *$ \\
$\begin{array}{l}\text { HLI } \\
\text { Gaughan et al. (2002) }\end{array}$ & $0.286^{* *}$ & $0.542^{* *}$ \\
$\begin{array}{l}\text { PRR } \\
\text { Eigenberg et al. } \\
(2002,2003)\end{array}$ & $0.114^{* *}$ & $0.344^{* *}$ \\
\hline
\end{tabular}

ns $=$ non-significant

** $\mathrm{P}<0.01$.

show as the $T_{r}$ and $F_{r}$ points tend to adhere at the respective regression lines. Besides, ETI is simpler to use, as it requires only information about air temperature, air humidity and wind speed. Notwithstanding the same data are required also by HLI, this index needs additional information about solar radiation. Gaughan et al. (2002) designed it as a guide to management of unshaded feedlot beef cattle during hot weather in Australia. Perhaps the predicted black globe temperature $\left(T_{g} *\right)$ used in the calculation of HLI could be substituted by the measured $T_{g}$ with advantage, thus avoiding the use of solar radiation determinations $\%$ which are hard to obtain for most locations. A test done with the present data by substituting $T_{g}$ for $T_{g}{ }^{*}$ showed little difference in the results.

By inspection of Figures 4 and 6 some points of alert can be suggested for the use of ETI and HLI in tropical regions (Table 3).

Finally, it must be remembered that the present index evaluation was done on Holstein and Jersey cows that are relatively adapted to the tropical environment of most Brazilian territory. 

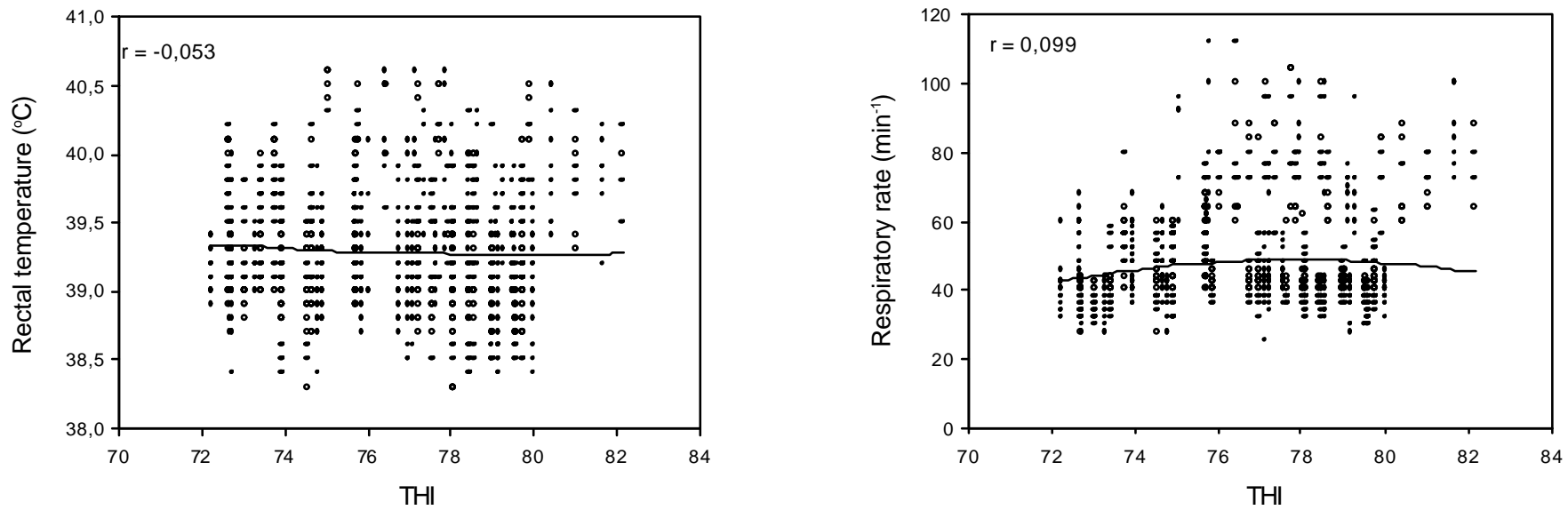

Figure 2 - Regression of the temperature-humidity index (THI) on rectal temperature and respiratory rate of Holstein and Jersey cows in a tropical environment.
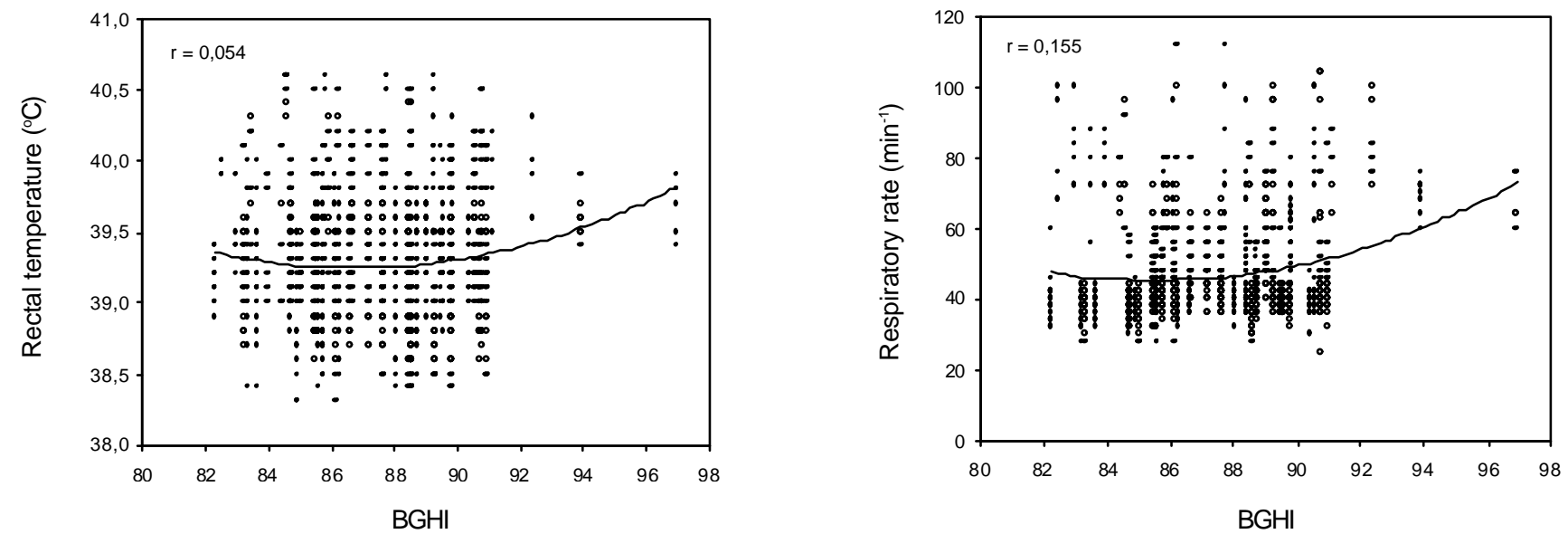

Figure 3 - Regression of the black globe-humidity index (BGHI) on rectal temperature and respiratory rate of Holstein and Jersey cows in a tropical environment.
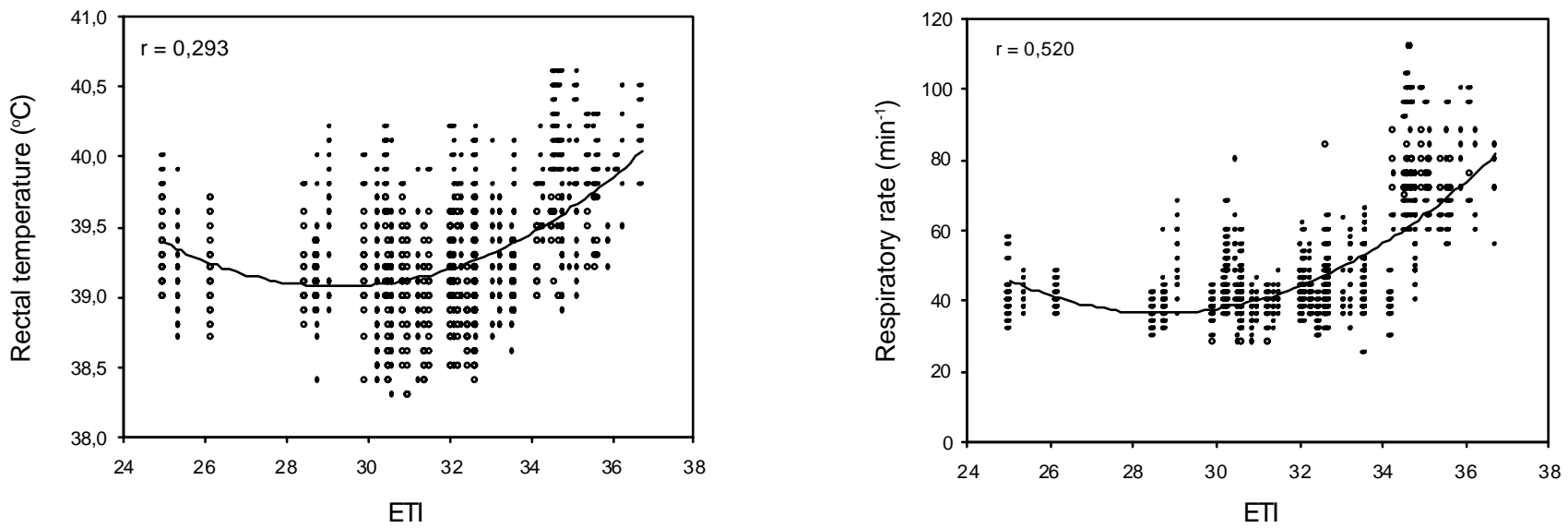

Figure 4 - Regression of the equivalent temperature index (ETI) on rectal temperature and respiratory rate of Holstein and Jersey cows in a tropical environment. 

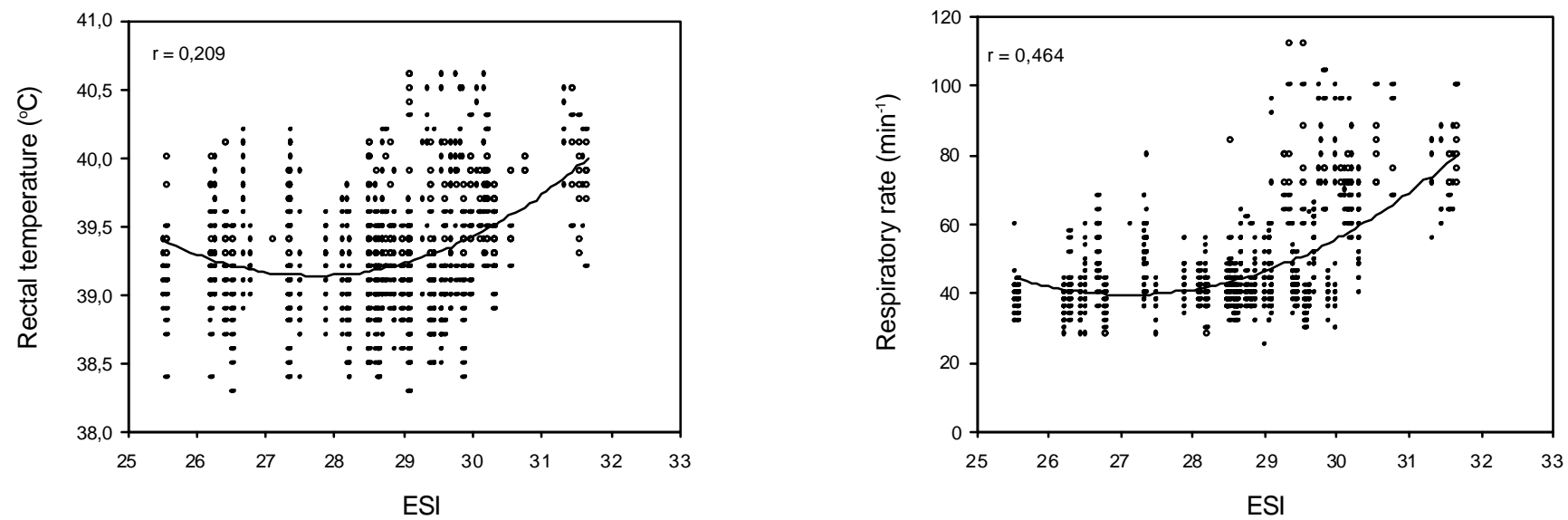

Figure 5 - Regression of the environmental stress index (ESI) on rectal temperature and respiratory rate of Holstein and Jersey cows in a tropical environment.
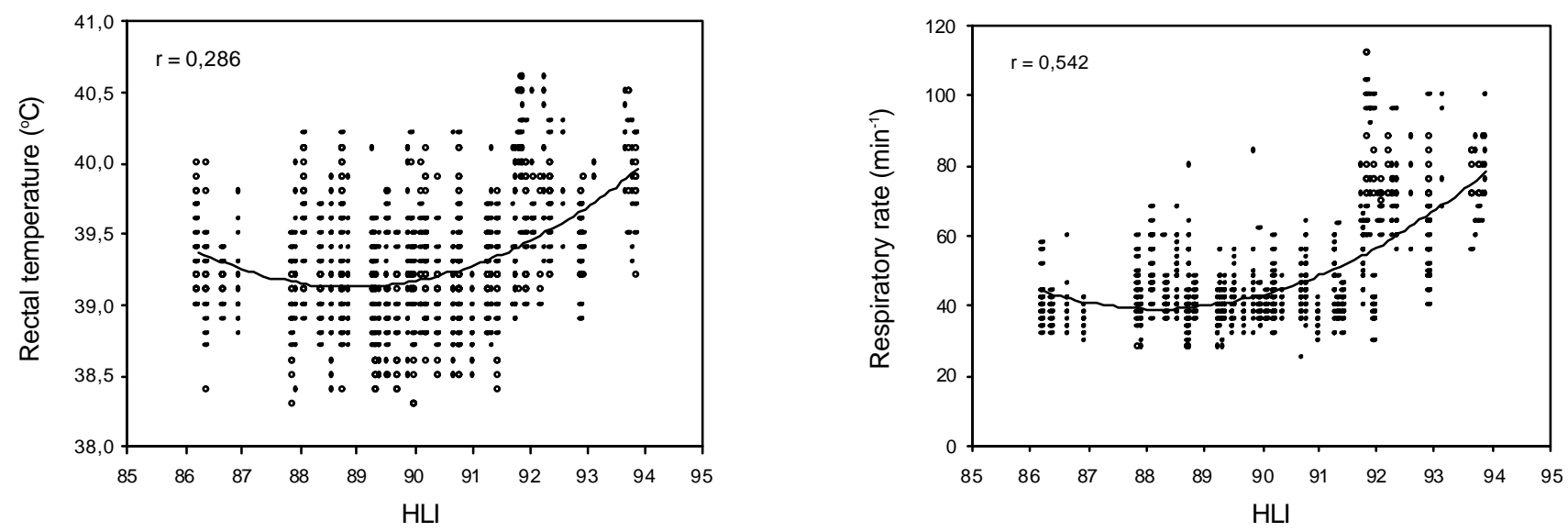

Figure 6 - Regression of the heat load index (HLI) on rectal temperature and respiratory rate of Holstein and Jersey cows in a tropical environment.
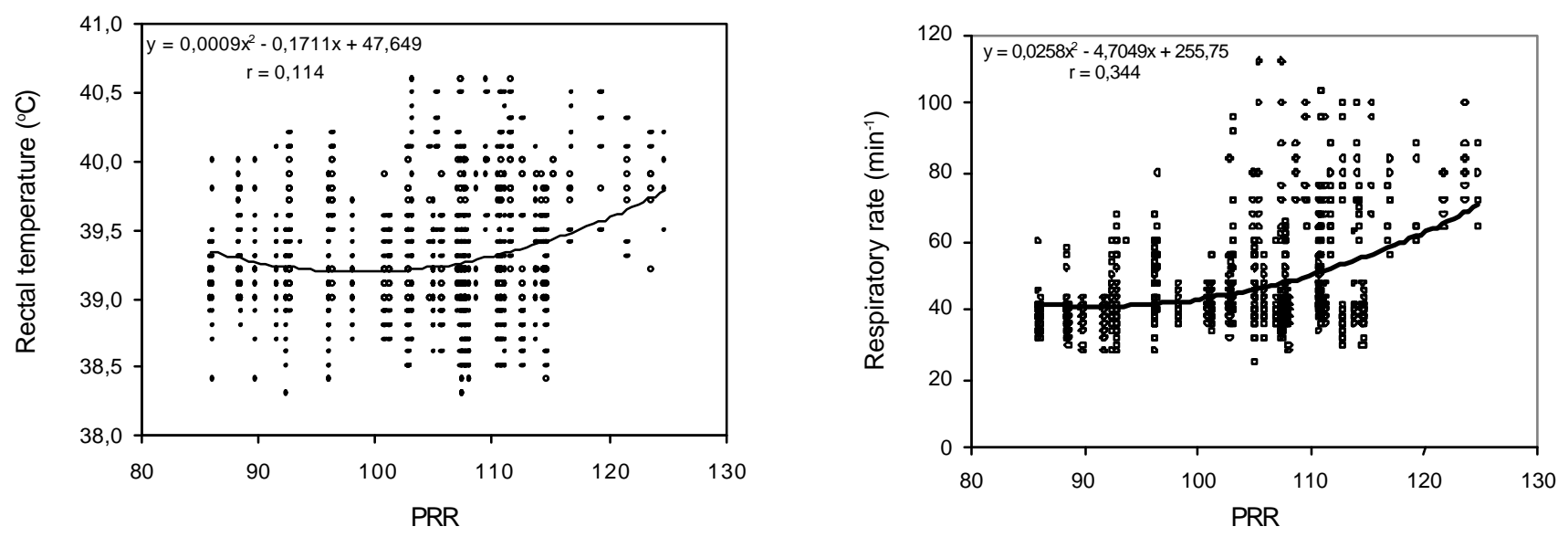

Figure 7 - Regression of the respiratory rate predictor (RRP) on rectal temperature and respiratory rate of Holstein and Jersey cows in a tropical environment. 
Table 3 - Suggested alert categories for the use of two indexes (ETI and $\mathrm{HLI}$ ) in a tropical region

\begin{tabular}{lcc}
\hline Alert category & ETI & HLI \\
\hline Safe & $<30$ & $<89$ \\
Caution & $30-34$ & $89-92$ \\
Extreme caution & $34-38$ & $92-95$ \\
Danger & $>38$ & $>95$ \\
\hline
\end{tabular}

\section{Conclusions}

THI (temperature-humidity index) and BGHI (black globe-humidity index) are not correlated with physiological responses of dairy cattle to a tropical environment. Therefore, they should not be used in such an environment for dairy cattle thermal stress specification.

ETI (equivalent temperature index) showed significant correlations of 0.293 with rectal temperature and 0.520 with respiratory rate, while HLI (heat load index) presented 0.286 and 0.542 , respectively. They were considered as the best of the five indexes to evaluate tropical environments for dairy cattle.

\section{Acknowledgements}

The authors acknowledge the valuable technical help from Mario Cardoso de Albuquerque Neto, Renata Maria Gomes Dantas, Mirella Gurgel and Andréa Souza, graduate students of Animal Science at Universidade Federal do Rio Grande do Norte in Natal.

\section{Literature Cited}

BAETA, F.C.; MEADOR, N.F.; SHANKLIN, M.D. et al. Equivalent temperature index at temperatures above the thermoneutral for lactating cows. In: MEETING OF THE AMERICAN SOCIETY OF AGRICULTURAL ENGINEERS, 1987, Baltimore. Proceedings... Baltimore: American Society of Agricultural Engineers, 1987. [mimeo.]

BEDFORD, T.; WARNER, C. The globe thermometer in studies of heating and ventilation. Journal of Hygiene, v.34, p.458473, 1934.

BOND, T.E.; KELLY, C.F. The globe thermometer in agricultural research. Agricultural Engineering, v.36, p.251-255 and $260,1955$.

BUFFINGTON, D.E.; COLLAZO-AROCHO, A.; CANTON, G.H.; PITT, D. et al. Black globe-humidity index (BGHI) as a comfort equation for dairy cows. Transactions of the A.S.A.E., v.24, p.711-714, 1981

EIGENBERG, R.A.; BROWN-BRANDL, T.M.; NIENABER, J.A. et al. Dynamic response of feedlot cattle to shade and no-shade. In: MEETING OF THE AMERICAN SOCIETY OF AGRICULTURAL ENGINEERS, 2002, St Joseph. Proceedings... St Joseph: American Society of Agricultural Engineers, 2002. [mimeo.].
EIGENBERG, R.A.; NIENABER, J.A.; BROWN-BRANDL, T.M. Development of a livestock safety monitor for cattle. In: MEETING OF THE AMERICAN SOCIETY OF AGRICULTURAL ENGINEERS, 2003, St Joseph. Proceedings... St Joseph: American Society of Agricultural Engineers, 2003. [mimeo.].

GAUGHAN, J.G.; GOOPY, J.; SPARK, J. Excessive heat load index for feedlot cattle. Sydney: MLA Ltda, 2002. (Meat and Livestock-Australia Project Report, 316). [mimeo.].

HAHN, G.L.; MADER, T.I.; EIGENBERG, R.A. Perspective on development of thermal indices for animal studies and management. In: Interactions between climate and animal production. Wageningen: Wageningen Academic Publications, 2003. p.31-44. (EAAP Technical Series, 7).

LIST, R.J. Smithsonian meteorological tables. 6.ed. Washington: Smithsonian Institution Press, 1971.

McARTHUR, A.J. Thermal interaction between animal and microclimate: a comprehensive model. Journal of Theoretical Biology, v.126, p.203-238, 1987.

McGOVERN, R.E.; BRUCE, J.M. A model of the thermal balance for cattle in hot conditions. Journal of Agricultural Engineering Research, v.77, n.1, p.81-92, 2000.

MONTEITH, J.L.; UNSWORTH, M.H. Principles of environmental physics. 2.ed. London: Edward Arnold, 1990. 291 p.

MORAN, D.S.; PANDOLF, K.B.; SHAPIRO, Y. et al. An environmental stress index (ESI) as a substitute for the wet bulb globe temperature (WBGT). Journal of Thermal Biology, v.26, p.427-431, 2001.

PINHEIRO, M.G.; SILVA, R.G. Pelame e produção de vacas da raça Holandesa em ambiente tropical. I. Características do pelame. Boletim de Indústria Animal, v.55, p.1-6, 1998.

SILVA, R.G. Introdução à bioclimatologia animal. São Paulo: Nobel, 2000a. 286p.

SILVA, R.G. Um modelo para a determinação do equilíbrio térmico de bovinos em ambientes tropicais [A model for the assessment of thermal balance of cattle in tropical environments]. Revista Brasileira de Zootecnia, v.29, n.4, p.1244-1252, 2000b.

SILVA, R.G. Carga térmica radiante: revisando a técnica de avaliação. Engenharia Rural, v.13, p.77-84, 2002.

SILVA, R.G.; BARBOSA, O.R. Thermal comfort index for sheep. In: INTERNATIONAL CONGRESS OF BIOMETEOROLOGY, 13., 1993, Calgary. Proceedings... Calgary: International Society of Biometeorology, 1993. v.2, p.383-392.

THOM, E.C. The discomfort index. Weatherwise, v.12, p.5759, 1959.

TURNPENNY, J.R. Thermal balance of livestock. 1. A parsimonious model. Agricultural and Forest Meteorology, v.101, p.1527, 2000a.

TURNPENNY, J.R. Thermal balance of livestock. 2. Applications of a parsimonious model. Agricultural and Forest Meteorology, v.101, p.29-52, 2000b.

UDO, H.J.M. Hair coat characteristics in Friesian heifers in the Netherlands and Kenya. (S.L.): Meded. Landbouwhogeschool Wageningen, 1978. 135p.

VERNON, H. The measurement of radiant heat in relation to human comfort. Journal of Industrial Hygiene, v.14, p.95-111, 1932.

YAMAMOTO, S. The assessment of thermal environment for farm animals. In: WORLD CONGRESS ON ANIMAL PRODUCTION, 5., 1983, Tokyo. Proceedings... Tokyo: Japanese Society of Zootechnical Science, 1983. v.1, p.197-204. 